\title{
IS BIGGER BETTER? THE IMPACT OF THE SIZE OF BANKS ON CREDIT RATINGS
}

\section{PATRYCJa Chodnicka-JaWORSKA ${ }^{1}$}

Abstract

\begin{abstract}
The aim of the paper was to analyse the factors influencing European banks' credit ratings by taking into account the size of these institutions. A literature review onthe indicators that can impact bank notes has been made. As a result, the following hypotheses have beendrawn:banks' capital adequacy, profitability, liquidity and management quality have a significant influence on bank credit ratings. Bigger banks receive higher credit ratings than the smaller ones in similar financial conditions. To verify the presented hypotheses ordered logit panel data models have been used. The analysis has been prepared by using the quarterly data from the Thomson Reuters database for the period between 1998 to 2015. The European banks' long-term issuer credit ratings proposed by S\&P, Fitch and Moody are used as dependent variables. The sample has been divided into subsamples according to the size of a bank andbanking sector and capitalization.
\end{abstract}




\section{INTRODUCTION}

Credit rating agencies are responsible for the reduction of asymmetry of information between an investor and an issuer. One of the main users of credit ratings are banks. They take them into consideration when analyzing credit risk, default risk, investment decisions and the corresponding banking. They are also obliged to have notes, especially if they cooperate with financial institutions from other countries.

At the moment 47 credit rating agencies are registered in the European Union, but only three of them have got $90 \%$ of the market share. These institutions comprise Fitch, Standard \& Poor's and Moody's. They are called the "Big Three". When analyzing default risk, they take into consideration the macroeconomic risk, the stability and quality of the financial market and the condition of the issuer.

Because banks are the main users of credit ratings, the following research question has been studied: which factors determine banks' credit ratings? As a result, the aim of the paper has been to analyze the factors influencing the European banks' credit ratings by taking into account the size of these institutions. Two hypotheses have been drawn. The first one seems as follows: banks' capital adequacy, profitability, liquidity and management quality have asignificant influence on the banks' credit ratings. The second one is: bigger banks receive higher credit ratings than the smaller ones in similar financial conditions. To verify these hypotheses ordered logit panel data models have been used. The analysis has been prepared by using the quarterly data for the period from 1998 to 2015 for European banks.

The paper has been organized as follows: Section 2 is a description of the previous research onthe factors that can influence banks' credit ratings by taking into consideration the size of the entities. Next the data description and the methodology used to verify the presented hypotheses have been presented. Section 4 is a presentation of the findings with conclusions.

\section{LITERATURE REVIEW}

To verify the default risk of an issuer, credit rating agencies take into consideration financial and nonfinancial indicators. The most popular is research based on corporate credit ratings. There are only a few papers that notice banks' credit ratings indicators. This research usually takes the whole population of banks into consideration to estimate the default risk. In this section the previous research about this phenomenon will be explored.

The analysis about the determinants influencing banks' credit ratings has been prepared for different subsamples. In most cases banks from different countries have been studied (Shen et al., 2012; Bellotti et al., 2011a; Bellotti et al., 2011b; Chodnicka-Jaworska, 2017), but some study national banking sectors, i.e. Slovenia (BrezigarMasten et al., 2015), Australia (McDonald \& Eastwood, 2000), United States (Estrella et al., 2000; BissoondoyalBheenick, Treepongkaruna, 2011), and United Kingdom (Bissoondoyal-Bheenick, Treepongkaruna, 2011) exists. Also, the period of time taken for the analysis (Shen et al. (2012) - 86 countries during 2002 - 2008; Bellotti et al. (2011a; 2011b) - countries in the period between 2000 and 2007) have been distinguished.

In most of the presented research the goal of the analysis was to verify the factors influencing banks' notes, but there are also other objectives. For example, King et al. (2016) tried to prepare standalone credit ratings to verify banks' creditworthiness from a stakeholders' point of view. They look into logarithmized assets and securitization, common equity to total assets, liquidity ratio, ROA, and short-term funding as dependent factors.

The analysis has been made for different subsamples. The size of banks has been analyzed by King et al. (2016), but they did not prepare the research according to the size of the institution, as it was only one of the determinants to verify. Hau, Langfield and Marques-Ibanez (2012) found that larger and more leveraged banks receive systematically more favorable credit ratings, which amounts to an economically significant competitive distortion. Credit ratings during the moment of the financial crisis were examined by Brezigar-Masten et al. (2015). They suggest that during the financial crisis the predictive accuracy was lowest for domestically owned banks and, within this group, for small banks. These institutions had also the largest incentives to undervalue risk because their portfolios were more exposed to non-performing loans and had limited possibilities to raise additional capital. They also found that given that credit ratings are closely related to the rates of loan-loss provisions, an underestimation of credit risk served to inflate banks' books. Hau, Langfield and Marques-Ibanez (2012) found that credit ratings become more informative during a financial crisis. The type of credit ratings has been verified by Pagratis and Stringa 
(2007). They divided samples according to investment and subinvestment grades. Another division was proposed by Packer and Taraschev (2011). They verified the reaction of banks' credit ratings during a crisis according to the size of the institution and the level of the countries' economic development. Shen et al. (2012) examined banks' credit ratings according to the asymmetry of information in particular countries. The results show that there is an impact of the asymmetry of information on banks' notes. One of the basic goals of countries that want to improve banks' ratings is to reduce this phenomenon. They also verified the influence of a country's development level, geographical location, industrial environment quality, bureaucracy, and corruption level.One of the most popular divisions is verification of factors influencing banks' notes depending on the agency. Laere et al. (2012) prepared an analysis for Moody's and S\&P's and found that the one by Moody's is more sensitive to the condition of an economy. An analysis based on the level of the banking sector consolidation has been made by Poon, Lee and Gup (2007). They found that credit ratings of unconsolidated banks are higher. The same situation has been observed for unsolicited notes.

More popular are researchers taking into account the size of banks to verify their default and credit risk. For example, Jacobson et al. (2006) found that default risk is most likely not homogeneous within rating classes. Their findings suggest that there is a difference between the implied loss distributions of two banks with equal „regulatory” risk profiles. Such variation is likely to translate into different levels of the required economic capital. They also found that not only the design of a rating system itself, but also the portfolio's rating grade composition, the size of a bank, the preferred level of insolvency risk for a bank, and the forecast horizon influence significantly the probability of default.

The analysis has been prepared by using different indicators. Pagratis and Stringa (2007) take into consideration provisions, profitability, cost efficiency, liquidity, short-term interest rates and bank-size performance, as those which explain ratings well. The classification on investment and sub-investment credit ratings mentioned before resulted in differences in the obtained results. Tier 1 capital ratios appear to impact sub-investment ratings, but not of investment grade. They also identified an asymmetric effect of profitability on ratings, with negative shocks in bank profits having a larger impact on ratings than positive shocks of equal magnitude. Liquidity and ratings are nonmonotonically related, possibly due to endogeneity effects. The impact of profitability, liquidity, capital adequacy, efficiency and quality factors has been measured by Shen et al. $(2012)^{2}$ and Bissoondoyal-Bheenick et al. (2011) ${ }^{3}$. Poon et al $(1999)^{4}$ took into consideration 100 variables. These indicators have been classified according to profitability, efficiency, structure of assets, interests, leverage and risk. Chodnicka-Jaworska $(2016)^{5}$ analyzed the impact of CAMEL indicators. To verify the probability of default Estrella et al. (2000) took the following into consideration: total assets, risk weighted assets and gross revenues. They found that these three ratios are significant predictors of failure. The number of failed banks with ratings is very small, and the evidence in favor of ratings is somewhat mixed.In their analysis of the impact of financial indicators ${ }^{6}$ on banks' notes Bellotti et al. (2011a) found that these react to the financial condition, the countries' risk and the timing of the rating assignment. The unimportance of countries' credit ratings has been emphasized by Poon et al. (1999).

${ }^{2}$ capital adequacy ratio, cost to income, loan loss provisions to net interest revenues, logarithm of total assets, net income to total assets, liquid assets to deposits, short-term funding.

${ }^{3}$ net income to total assets, liquid assets to deposits and short-term funding, capital adequacy ratio, cost to income, loan loss provisions to net interest revenues.

${ }^{4}$ net interest margin, net interest revenue to average total assets, pretax operating income to average total assets, return on average assets, return on average equity, dividend payout, cost to income ratio, loan loss reserves to gross loans, loan loss provisions to net interest revenue, loan loss reserves to non-performing loans, non-performing loans to gross loans, net charge off to average gross loans, net charge off to net income before loan loss provisions interbank ratio, loans to total assets, loans to customer and short-term funding, loans to total deposits and borrowings, liquid assets to customer and short-term funding, liquid assets to total deposits and borrowings, tier 1 capital ratio, capital adequacy ratio, equity to total assets, equity to loans, equity to customer and short-term funding, logarithm of book value of total assets, logarithm of book value of trading securities, year dummy, proportion of solicited ratings in the respective country of the year, no. of overseas exchanges on which the bank was listed, no. of overseas subsidiaries held by the issuer.

${ }^{5}$ Tier 1 , leverage ratio, $z$-score ratio, loan loss provisions to average total loans, non - performing loans to total loans, efficiency ratio, securities to earnings assets, net interest income ratio, return on equity, return on assets, operating leverage, loan growth, deposit growth, loans to deposit, short-term borrowing to total liabilities, liquid assets to total assets, GDP growth, inflation, country's credit rating. 
In their opinion loan loss provisions and profitability explain $63.1 \%$ of credit ratings. Macroeconomic factors and their importance have been analysed by BissoondoyalBheenick and Treepongkaruna (2011). Hassan and Barrell (2013) suggest that only the bank size, liquidity, efficiency and profitability significantly influence the banks' notes (from $74 \%$ to $78 \%$ of the sample banks) from all analysed determinants ${ }^{7}$. The importance of the efficiency, profitability, and the proportion of loans in the assets have been distinguished by Öğüt et al. (2012).

The methods of verifying the significance of credit rating factors implemented in the research are: ordered probit (Bellotti et al., 2011a, 2011b, Bissoondoyal-Bheenick \& Treepongkaruna (2011), panel data models (Ötker-Robe \& Podpiera, 2010; Chodnicka - Jaworska, 2016), support vector machines (SVM) (Ogut et al. 2012, Bellotti et al., 2011a, 2011b), ordered logit models (Bellotti et al., 2011a, 2011b; Ogut et al. 2012; Hassan \& Barrell, 2013), Artificial Neural Network, multiple discriminant analysis (Ogut et al. 2012). In this paper ordered probit panel data models, described in the next section, have been used.

The literature review indicates several research problems. The first one relies on the type of determinants that can be analysed to verify credit ratings. Particular studies treat different variables that can influence banks' credit ratings. In practice they are differentiated according to the sample that have been used in the analysis. Sometimes they are different for the same credit rating, published for the same agency. The next problem is strictly connected with the lack of the analysis of the impact of the size of bank on the credit ratings. It can be strictly connected with, for example, the possibility of financial support from government, when there may be problems with the solvency risk.

\footnotetext{
7 logarithm of total assets, total assets deflated by business volume, total long term funding minus total equity all deflated by total assets, interest-bearing liabilities to earning assets, net interest margin, net interest income less loan impairment charges all deflated by earning assets, cost to income, non-interest expenses to assets, net loans to total assets, loans to customer deposits, net charge off or the amount written-off from loan loss reserves less recoveries to gross loans, growth of gross loans of a bank deflated by total growth of gross loans of the sample banks, equity to total assets, subordinated borrowing to total assets.
}

\section{METHODOLOGY AND DATA DESCRIPTION}

The analysis has been prepared for European banks from 24 countries $^{8}$. Long-term issuer credit ratings for the period between 1998 and 2015 have been used as a dependent variable. The quarterly data collected from the Thomson Reuters Database and banks' financial statements have been used for the research. Notes proposed by the three biggest credit rating agencies: S\&P's, Fitch and Moody's have been used for the analysis. Ratings have been decomposed linearly according to the methodology proposed by Ferri, Liu, Stiglitz (1999). The effects of the decomposition have been presented in Table 1.

The factors classified according to the CAMELstructure, i.e. capital adequacy, assets quality, management quality, earnings, liquidity, as well as market factors are used as independent variables. The list of independent factors has been presented in Table 2.

The analysis has been prepared for subsamples according to the size of institutions, the size of the banking sector, and the value of capitalization. This classification will help to provide information on whether any differences between the notes received by bigger and smaller banks have been observed. The size of the institution has been measured by the logarithm of assets. The division according to the size of the institution measured by the size of assets and the value of capitalization has been created by using the three-sigma rule of thumb which expresses a conventional heuristic that nearly all values are taken to lie within three standard deviations of the mean, and thus it is empirically useful to treat $99.7 \%$ probability as near certainty.

The analysis has been prepared by using the ordered probit panel data models. Probit is the probability unit which is then transformed into its cumulative probability value from a normal distribution. An ordered panel probit model is:

$$
y_{i t}^{*}=\beta F_{i t}^{\prime}+\gamma Z_{i t}+\delta(F * Z)_{i t}+\varepsilon_{i t}
$$

\footnotetext{
${ }^{8}$ Albania, Armenia, Austria, Belarus, Belgium, Bosna and Herzegovina, Bulgaria, Croatia, Cyrus, Czech Republic, Denmark, Estonia, Finland, France, Georgia, Germany, Greece, Hungary, Iceland, Ireland, Latvia, Liechtenstein, Lithuania, Luxembourg, Macedonia, Malta, Moldova, Monaco, Netherlands, Norway, Poland, Portugal, Romania, Russia, San Marino, Serbia, Slovakia, Slovenia, Spain, Sweden, Switzerland, Turkey, Ukraine, United Kingdom
} 
Table 1: Decomposition of Moody's, S\&P's and Fitch long-term issuer credit ratings

\begin{tabular}{|c|c|c|c|c|c|}
\hline \multicolumn{2}{|c|}{ Moody's Long-term Issuer Rating } & \multicolumn{2}{|c|}{ S\&P's Long-term Issuer Rating } & \multicolumn{2}{|c|}{ Fitch Long-term Issuer Rating } \\
\hline Rating & Code & Rating & Code & Rating & Code \\
\hline Aaa & 100 & AAA & 100 & AAA & 100 \\
\hline Aa1 & 95 & $\mathrm{AA}+$ & 95 & $\mathrm{AA}+$ & 94,74 \\
\hline $\mathrm{Aa} 2$ & 90 & AA & 90 & AA & 89,47 \\
\hline $\mathrm{Aa3}$ & 85 & AA- & 85 & AA- & 84,21 \\
\hline A1 & 80 & $A+$ & 80 & $A+$ & 78,95 \\
\hline A2 & 75 & A & 75 & A & 73,68 \\
\hline A3 & 70 & A- & 70 & A- & 68,42 \\
\hline Baa1 & 65 & $\mathrm{BBB}+$ & 65 & $\mathrm{BBB}+$ & 63,16 \\
\hline Baa2 & 60 & BBB & 60 & BBB & 57,89 \\
\hline Baa3 & 55 & BBB- & 55 & BBB- & 52,63 \\
\hline Ba1 & 50 & $\mathrm{BB}+$ & 50 & $\mathrm{BB}+$ & 47,37 \\
\hline $\mathrm{Ba} 2$ & 45 & BB & 45 & BB & 42,11 \\
\hline Ba3 & 40 & BB- & 40 & BB- & 36,84 \\
\hline B1 & 35 & $\mathrm{~B}+$ & 35 & $\mathrm{~B}+$ & 31,58 \\
\hline B2 & 30 & B & 30 & B & 26,32 \\
\hline B3 & 25 & B- & 25 & B- & 21,05 \\
\hline Caa1 & 20 & $\mathrm{CCC}+$ & 20 & $\mathrm{CCC}$ & 15,79 \\
\hline Caa2 & 15 & $\mathrm{CCC}$ & 15 & $\mathrm{CC}$ & 10,53 \\
\hline Caa3 & 10 & CCC- & 10 & C & 5,26 \\
\hline Caa & 5 & CC & 5 & $\mathrm{RD}$ & -5 \\
\hline C & 0 & NR & 0 & $\mathrm{D}$ & -5 \\
\hline WR & -5 & SD, D & -5 & WD & -5 \\
\hline NULL & 0 & NULL & 0 & & \\
\hline
\end{tabular}

Source: Own elaboration

Table 2: The list of independent variables

\begin{tabular}{|c|c|c|}
\hline Name of variable & Direction & Abbreviations \\
\hline \multicolumn{3}{|c|}{ Capital adequacy } \\
\hline tier 1 & + & tier $_{\text {it }}$ \\
\hline leverage ratio & + & $l e v_{i t}$ \\
\hline z-score & + & score $_{\text {it }}$ \\
\hline \multicolumn{3}{|c|}{ Assets quality } \\
\hline loan loss provisions as a percentage of the average total loans & - & $\| p_{i t}$ \\
\hline non-performing loans to total loans & - & $n p l_{i t}$ \\
\hline \multicolumn{3}{|c|}{ Management quality } \\
\hline efficiency ratio & - & $e f_{i t}$ \\
\hline securities as a percentage of earnings on assets & - & $\sec _{i t}$ \\
\hline \multicolumn{3}{|l|}{$\begin{array}{ll} & \text { Earnings }\end{array}$} \\
\hline net interest income ratio & $-1+$ & $n i i_{i t}$ \\
\hline return on equity & + & roe $_{i t}$ \\
\hline return on assets & + & roa $_{i t}$ \\
\hline operating leverage & + & $o p l_{i t}$ \\
\hline
\end{tabular}




\begin{tabular}{|c|c|c|}
\hline loan growth & $-1+$ & $\lg _{i t}$ \\
\hline deposit growth & + & $d g_{i t}$ \\
\hline \multicolumn{3}{|c|}{ Liquidity } \\
\hline loan to deposit ratio & - & $d e p_{i t}$ \\
\hline short-term borrowing to total liabilities & - & $s h t_{i t}$ \\
\hline liquid assets to total assets & - & $l i q_{i t}$ \\
\hline \multicolumn{3}{|c|}{ Market } \\
\hline effective GDP growth & + & $g d p_{i t}$ \\
\hline inflation & - & $\inf _{\text {it }}$ \\
\hline country's risk & + & $c r_{i t}$ \\
\hline
\end{tabular}

Source: Own elaboration

where $y^{*}{ }_{i t}$ is an unobservable latent variable that measures long term issuer credit rating of banki in period $t$ (Fitch Long-term Issuer Rating, S\&P Long - Term Issuer Rating, Moody's Long -Term Issuer Rating);

$F_{i t}$ is a vector of explanatory variables, i.e.:

$F_{i t}=\left[\right.$ tier $_{i t^{\prime}}$ lev $_{i t^{\prime}}$ score $_{i t^{\prime}} \| p_{i t^{\prime}}, n p l_{i t^{\prime}}$ ef $f_{i t^{\prime}} \sec _{i t^{\prime}}$

nii $_{i t^{\prime}}$ roe $_{i t^{\prime}}$ roa $_{i t^{\prime}}$ opl $l_{i t^{\prime}} \lg _{i t^{\prime}} d g_{i t^{\prime}}$ dep $_{i t^{\prime}} s h t_{i t^{\prime}}$

$\operatorname{liq}_{i t^{\prime}} g d p_{i t^{\prime}}$ inf ${ }_{i t^{\prime}} \mathrm{cr}_{i t^{\prime}}$ ass $\left._{i t^{\prime}} \operatorname{assgdp}_{i t^{\prime}} \operatorname{capgdp}_{i t}\right]$

where: tier $_{i t}$ is the Tier 1 ratio;

$\operatorname{lev}_{i t}$ is the leverage ratio;

score $_{i t}$ is the z-score ratio;

$\| p_{i t}$ is the loan loss provisions as a percentage of average total loans;

$n p l_{i t}$ is the non - performing loans to total loans;

$e f_{i t}$ is the efficiency ratio;

$\sec _{i t}$ is the value of securities as a percentage of earnings assets;

$n i i_{i t}$ is the net interest income ratio;

roe $_{i t}$ is the return on equity;

roa $_{i t}$ is the return on assets;

$o p l_{i t}$ is the operating leverage;

$\lg _{i t}$ is the loan growth;

$d g_{i t}$ is the deposit growth;

$d_{e p} p_{i t}$ is the ratio of loans to deposit;

sht $t_{i t}$ is the value of short-term borrowing to total liabilities,

$l i q_{i t}$ is the value of liquid assets to total assets;

$g d p_{i t}$ is the GDP growth,

$\inf _{i t}$ is the inflation;

$\mathrm{Cr}_{i t}$ is the country's credit rating given by a particular credit rating agency (Fitch Long-term Issuer Rating, S\&P Long - Term Issuer Rating, Moody's Long -Term Issuer Rating);

$\operatorname{cap}_{i t}$ is the logarithm of banks' capitalization;

capgdp $p_{i t}$ is the bank capitalization as a percentage of GDP,

ass $_{i t}$ is the logarithm of banks' assets;

$\operatorname{assgdp}_{i t}$ is the banks' assets as a percentage of GDP,

$Z_{i t}$ contains time invariant regressors that are generally dummy variables

$\varepsilon_{i t}$ is a random disturbance term.

\section{FINDINGS}

The analysis of the factors influencing the European banks' credit ratings by taking into account the size of these institutions has been started for the summary statistic calculations. The results of the estimation have been presented in Table 3.

At first an analysis of the determinants of credit ratings proposed by Fitch was prepared. The results of the estimation have been presented in Table 4. Out of the capital adequacy indicators it is the tier 1 ratio which has got a significant impact. The leverage ratio has an insignificant influence on banks' notes in the sample of all banks. Taking into account the size of issuers analyzed as a logarithmized value of total assets, both of the variables are significant for bigger banks (bigger banks mean institutions that have got assets higher than 100 bln euros). The same situation has been observed for the division according to the value of capitalization (bigger banks mean institutions that have got capitalization higher than 6blneuros). For smaller issuers these 
Table 3: Summary statistics

\begin{tabular}{|c|c|c|c|c|c|}
\hline Variable & Obs & Mean & Std. Dev. & Min & Max \\
\hline ass & 7,101 & $1.22 \mathrm{e}+11$ & $2.96 e+11$ & 1465207 & $2.51 e+12$ \\
\hline lab & 7,046 & $1.17 e+11$ & $2.85 e+11$ & 121690.9 & $2.45 e+12$ \\
\hline nii & 288 & 3.342993 & 2.062914 & .496 & 14.697 \\
\hline ef & 528 & 49.07732 & 80.3074 & -1358.44 & 327.994 \\
\hline opl & 6,18 & 2.084361 & 374.1404 & -21059.2 & 10346.1 \\
\hline lev & 6,769 & 15.84086 & 41.02734 & -916.6667 & 1944.444 \\
\hline IIp & 5,408 & .9790568 & 37.92086 & -939.181 & 2524.49 \\
\hline npl & 1,323 & 16.67219 & 62.07641 & .000012 & 1431.78 \\
\hline tier1 & 3,133 & 11.85202 & 4.404751 & 1 & 52.3202 \\
\hline dep & 6,108 & 33.89172 & 945.023 & -.037852 & 59681.4 \\
\hline sec & 6,07 & 20.37762 & 16.94761 & 0 & 129.026 \\
\hline roa & 6,478 & .1957794 & 3.072931 & -94.7601 & 49.4816 \\
\hline roe & 445 & -.1839513 & 25.80748 & -436.544 & 57.7226 \\
\hline liq & 6,77 & .2650961 & .1632072 & 0 & 1.329167 \\
\hline lg & 5,692 & .0158678 & .2428442 & -6.955236 & 3.999034 \\
\hline dg & 5,636 & .021588 & .3287204 & -8.351819 & 8.321701 \\
\hline sht & 6,216 & 1.261429 & 15.31838 & -3.307692 & 382.3529 \\
\hline gdpg & 18,438 & 2.292871 & 3.534638 & -16.43029 & 13.8265 \\
\hline cpi & 18,294 & 205.1854 & 630.3739 & 36.8 & 6739.645 \\
\hline cap & 13,361 & $6.16 e+09$ & $1.54 \mathrm{e}+10$ & 40032.35 & $1.66 \mathrm{e}+11$ \\
\hline sp & 5,138 & 67.35014 & 24.02872 & -5 & 100 \\
\hline fitch & 4,548 & 22.45441 & 37.65751 & -5 & 94.7368 \\
\hline moody & 1,405 & 78.58363 & 19.49562 & -5 & 100 \\
\hline cr sp & 17,316 & 74.7638 & 26.43566 & -5 & 100 \\
\hline cr fitch & 16,161 & 25.26581 & 42.54134 & -5 & 100 \\
\hline cr moody & 13,897 & 66.9542 & 28.35881 & 0 & 100 \\
\hline
\end{tabular}

\section{Source: Own calculations}

variables are insignificant. If tier 1 ratio is higher by one percentage point, the credit ratings are lower by nearly 0.5 in the sample of bigger banks measured by the total assets and by 0.3 according to the value of capitalization. For the leverage ratio this relationship looks as follows: an increase by one percentage point of the leverage ratio causes a reduction of credit ratings by 0.05 and 0.03 respectively. The same relationship has been observed for Moody's and S\&P's notes (Tables 5 and 6). For Moody's notes a stronger impact of the leverage ratio has been observed, but the relation is positive. An increase of this index by one percentage point causes a rise of the credit ratings given for big banks by 0.2 . In the case of S\&P the presented variable is significant for both bigger and smaller issuers, but the reaction is stronger for the first of this group (0.14 versus 0.05$)$. Tier 1 ratio is significant for both subsamples, both for S\&P's and Moody's credit ratings, but the impact is stronger for smaller issuers. This relationship can be connected with two situations. First of all, bigger banks that have got higher adequacy ratios may be treated as those with higher risk by taking into account the size of the probability of losses for the financial system in the case of a default. On the other hand, bigger banks are usually more stable than smaller financial institutions, so as a result, smaller issuers should have higher ratios.

From assets quality indicators the impact of loan loss provisions as a percentage of the average total loans on banks' credit ratings has been verified. The significance of this variable has been emphasized especially in the case of bigger banks, both measured by the value of total assets and market capitalization. If this indicator increases by one percentage point, the ratings are decreased by 
2.6 for Fitch, 0.53 for Moody's and 0.22 for S\&P's. This relationship can be connected with the quality of the banks' loans.

The next group of determinants taken into analysis are management quality indicators. The value of securities as percentage of earnings on assets has been used for the analysis. This indicator has been significant for Fitch ratings, for bigger banks (0.08 for the sample of bigger banks measured by the value of total assets and 0.05 according to the value of market capitalization). In the case of Moody's, the impact is also positively correlated with credit ratings. The reaction is stronger for smaller issuers. It can be connected with the type of investment.

The earnings factors analyzed include the return on assets, operating leverage, loan growth and deposit growth. The first is the return on assets. The relationship between this indicator and credit ratings is differentiated. The results for Fitch ratings suggest that if the rates of return rise by one percentage point, notes are lower by 5.7 and 3.23 in the case of big banks. It can be connected with the opinion that higher profits generated by banks can be an effect of risky investments. A different relationship has been noticed for Moody's and S\&P'S credit ratings. In the case of S\&P's, an increase by one percentage point of this variable causes a rise of credit ratings by 3.01 when taking into account the size of assets, and 2.7 for the value of the capitalization market. The strongest reaction has been noticed for Moody's ratings (8.21 and 8.27). The relationship is positive for bigger banks, but for smaller institutions the impact is negative. The presented results suggest that smaller banks invest in a riskier way. The deposit growth is insignificant for the notes presented by Fitch and S\&P's, both for smaller and bigger institutions. The Moody's notes react negatively to these changes (-4.1 and -3.8) for the sample of large entities. Increasing the deposit base can create additional interest costs, especially in the case of bigger banks. The described variable should be compared with loan growth. Extending loans is a source of additional interest income. The described relationship is especially significant for the notes presented for smaller banks by Fitch and S\&P's, but the direction of the relationship is differentiated. In the case of Fitch ratings react positively to a loan growth (0.75 and 0.95). The relationship confirms the previous opinion. S\&P's ratings are negatively correlated with this indicator (-0.94). Smaller banks can have a higher value of the performing loans in the credit portfolio, which can generate credit risk. The last variable that has been analyzed in the presented group of determinants is the operating leverage. It influences insignificantly the notes presented by Fitch and the coefficient equals nearly zero in the case of large banks that have been assessed by S\&P's. The operating leverage influences negatively the notes received by large institutions (-0.1 and -0.1) and positively the smaller ones (0.02). The impact of the described variable is also minimal.

The last of the fundamental group of indicators are liquidity factors. This group comprises the loan to deposit ratio, the short-term borrowing to total liabilities ratio and the value of the liquid assets to total assets. The first indicator that has been taken into analysis is the loan to deposit ratio. The research confirms the previous assumption about the negative impact of this variable on credit ratings. The strongest reaction has been noticed for Fitch ratings. No differences between smaller and bigger banks have been observed taking into consideration the size of assets. In the case of the classification according to the value of the capitalization market, a higher negative impact has been noticed for larger institutions (-3.78 versus -2.60).A significant reaction in the case of smaller banks has also been noticed for S\&P's ratings. A stronger reaction for larger issuers has been noticed for the Moody's sample. The relationship is strictly connected with the type of loans having particular banks in their credit portfolio. Bigger banks that have got a larger value of the described indicator can create additional systemic risk because their default can have an effect on the condition of the economy and other institutions. On the other hand, a "too big to fail" phenomenon can occur.

The value of liquid assets to total assets is the next indicator that has been analyzed. The direction of the impact confirms previous assumptions. The impact of this variable has been observed for Fitch notes, both for smaller and bigger banks. A stronger influence has been noticed for smaller institutions. The same situation has been noted for S\&P's, but in this case a statistically significant impact has not been observed for larger banks. Moody's ratings are sensitive to the value of liquid assets to total assets only for the sample of bigger banks. This situation can be connected with the cost of maintaining a high liquidity. Smaller banks can have a higher value of this ratio. On the other hand, they may invest less money in securities. The last of this group of indicators is the short-term borrowing to total liabilities ratio. Fitch notes are positively correlated. A stronger relation has been observed for larger institutions than the smaller banks, in 
ß. Patrycja Chodnicka-Jaworska

Table 4: Estimation of determinants influencing Fitch banks' credit ratings by taking into consideration the size of banks and their capitalization

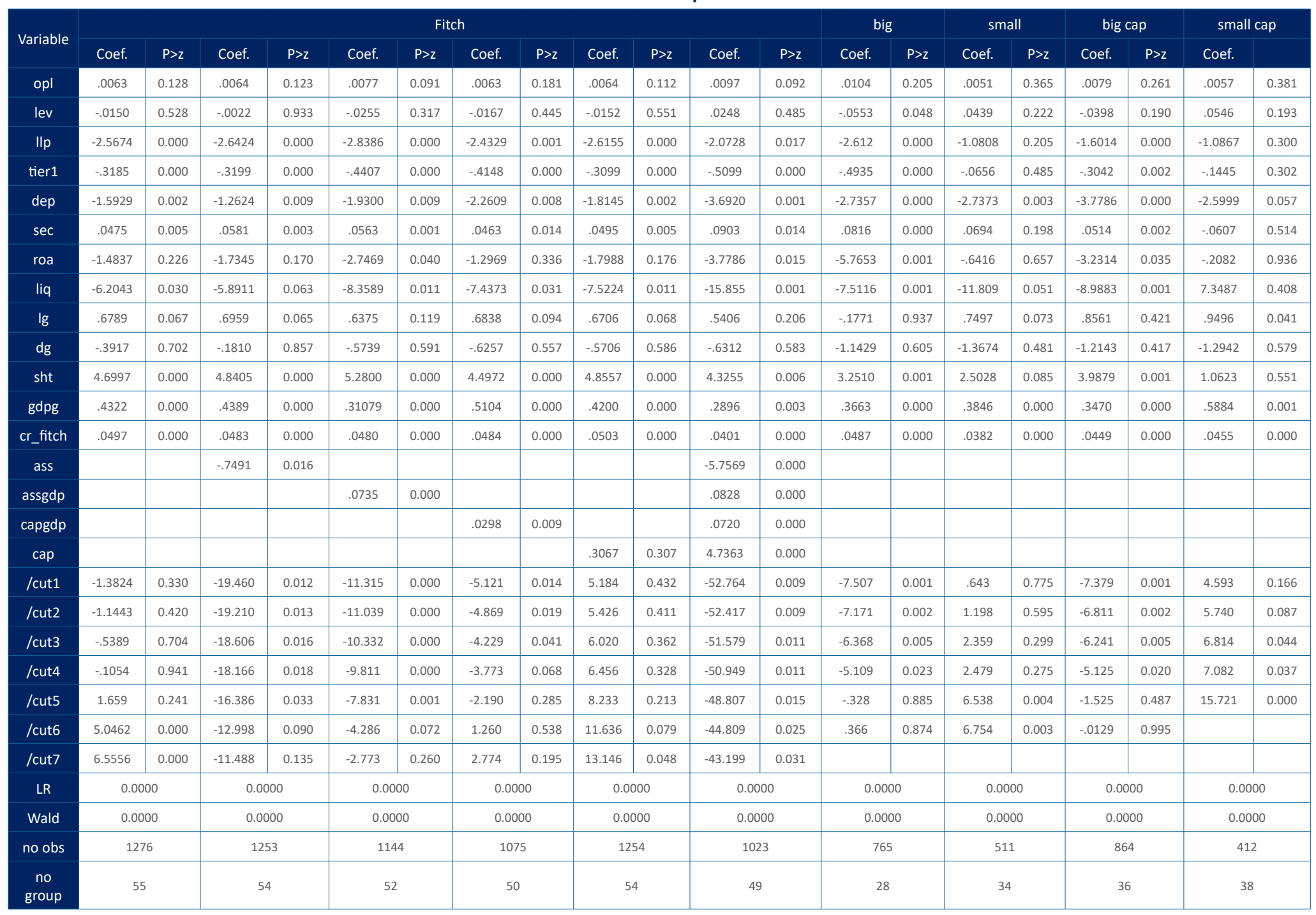

Source: Own calculations 
2. Patrycja Chodnicka-Jaworska

Is bigger better? The impact of the size of banks on credit ratings $\bar{C}$

Table 5: Determinants influencing Moody's banks' credit ratings by taking into consideration the size of banks and their capitalization

\begin{tabular}{|c|c|c|c|c|c|c|c|c|c|c|c|c|c|c|c|c|c|c|c|c|}
\hline \multirow{2}{*}{ Moody } & \multicolumn{12}{|c|}{ Moody } & \multicolumn{2}{|c|}{ big } & \multicolumn{2}{|c|}{ small } & \multicolumn{2}{|c|}{ big cap } & \multicolumn{2}{|c|}{ small cap } \\
\hline & Coef. & $P>Z$ & Coef. & $P>z$ & Coef. & $P>z$ & Coef. & $P>Z$ & Coef. & $P>Z$ & Coef. & $P>z$ & Coef. & $P>Z$ & Coef. & $P>Z$ & Coef. & $P>z$ & Coef. & $P>Z$ \\
\hline opl & -.0077 & 0.027 & -.0087 & 0.014 & -.0109 & 0.002 & -.0088 & 0.017 & -.0076 & 0.031 & -.0144 & 0.000 & -.0109 & 0.006 & .0203 & 0.076 & -.0118 & 0.004 & .0132 & 0.200 \\
\hline lev & .1552 & 0.000 & .1558 & 0.000 & .1468 & 0.000 & .0849 & 0.000 & .1557 & 0.000 & .0781 & 0.002 & .2072 & 0.000 & .0008 & 0.989 & .2028 & 0.000 & .0463 & 0.314 \\
\hline$\| p$ & .4246 & 0.014 & .4443 & 0.012 & .5598 & 0.002 & .4746 & 0.010 & .4207 & 0.015 & .6540 & 0.002 & -.5371 & 0.006 & -3.8534 & 0.587 & -.5599 & 0.005 & -6.1236 & 0.164 \\
\hline tier1 & -.2072 & 0.000 & -.2501 & 0.000 & -.3017 & 0.000 & -.5116 & 0.000 & -.2089 & 0.000 & -.6169 & 0.000 & -.1659 & 0.000 & -.5331 & 0.002 & -.1661 & 0.000 & -.5209 & 0.001 \\
\hline dep & -.0215 & 0.597 & .0076 & 0.864 & .0209 & 0.687 & .0174 & 0.746 & -.0207 & 0.614 & .0721 & 0.229 & -1.5029 & 0.004 & .2114 & 0.063 & -1.3148 & 0.015 & .1849 & 0.030 \\
\hline sec & .0183 & 0.083 & .0239 & 0.027 & .0219 & 0.051 & .0236 & 0.046 & .0185 & 0.081 & .0274 & 0.029 & .0221 & 0.047 & .2167 & 0.010 & .0170 & 0.171 & -.0363 & 0.210 \\
\hline roa & 5.8345 & 0.000 & 6.9455 & 0.000 & 9.5726 & 0.000 & 5.9689 & 0.000 & 5.7723 & 0.000 & 10.4846 & 0.000 & 8.2147 & 0.000 & -10.4479 & 0.027 & 8.5719 & 0.000 & -6.1363 & 0.148 \\
\hline liq & -.4685 & 0.789 & -2.1635 & 0.248 & -2.2001 & 0.291 & .2097 & 0.919 & -.5568 & 0.757 & -3.1498 & 0.212 & -4.2871 & 0.036 & -1.2253 & 0.870 & -3.4023 & 0.106 & 7.1101 & 0.232 \\
\hline $\lg$ & -1.3526 & 0.430 & -2.1287 & 0.228 & -2.2076 & 0.290 & -2.1841 & 0.274 & -1.3911 & 0.420 & -2.3417 & 0.279 & 1.2585 & 0.569 & -2.8887 & 0.631 & 1.1058 & 0.634 & -5.8982 & 0.151 \\
\hline dg & -.8482 & 0.330 & -.4157 & 0.654 & .4305 & 0.735 & .2724 & 0.838 & -.8361 & 0.339 & 1.1073 & 0.443 & -4.1033 & 0.008 & 3.2973 & 0.274 & -3.4877 & 0.032 & 2.3988 & 0.263 \\
\hline sht & 1.4201 & 0.065 & 2.4522 & 0.006 & .6622 & 0.465 & .3029 & 0.744 & 1.4254 & 0.065 & 2.3198 & 0.040 & 1.7652 & 0.059 & 12.5519 & 0.001 & 1.5954 & 0.094 & 12.5484 & 0.001 \\
\hline gdpg & -.0493 & 0.150 & -.0536 & 0.122 & -.0970 & 0.012 & -.2027 & 0.000 & -.0525 & 0.162 & -.1811 & 0.000 & .0714 & 0.048 & -.1674 & 0.319 & -.0396 & 0.304 & -.0898 & 0.530 \\
\hline $\begin{array}{c}\text { cr_mo- } \\
\text { ody }\end{array}$ & .2566 & 0.000 & .2641 & 0.000 & .2689 & 0.000 & .2611 & 0.000 & .2561 & 0.000 & .2710 & 0.000 & .2183 & 0.000 & .5581 & 0.001 & .2179 & 0.000 & .4608 & 0.000 \\
\hline ass & & & 1.5861 & 0.005 & & & & & & & 2.7308 & 0.000 & & & & & & & & \\
\hline assgdp & & & & & .0104 & 0.224 & & & & & .0087 & 0.373 & & & & & & & & \\
\hline capgdp & & & & & & & .0374 & 0.001 & & & .0429 & 0.001 & & & & & & & & \\
\hline cap & & & & & & & & & .0540 & 0.839 & 1.4218 & 0.000 & & & & & & & & \\
\hline /cut1 & 15.56 & 0.000 & 56.44 & 0.000 & 16.29 & 0.000 & 11.87 & 0.000 & 16.69 & 0.005 & 48.75 & 0.000 & 14.54 & 0.000 & 25.87 & 0.017 & 14.92 & 0.000 & 20.73 & 0.005 \\
\hline /cut2 & 16.02 & 0.000 & 56.92 & 0.000 & 16.85 & 0.000 & 12.45 & 0.000 & 17.16 & 0.004 & 49.32 & 0.000 & 17.68 & 0.000 & 26.76 & 0.015 & 18.05 & 0.000 & 21.49 & 0.004 \\
\hline /cut3 & 18.40 & 0.000 & 59.57 & 0.000 & 19.58 & 0.000 & 15.58 & 0.000 & 19.55 & 0.001 & 52.83 & 0.000 & 18.60 & 0.000 & 33.49 & 0.007 & 19.01 & 0.000 & 27.63 & 0.002 \\
\hline /cut4 & 19.82 & 0.000 & 61.12 & 0.000 & 20.67 & 0.000 & 16.98 & 0.000 & 20.98 & 0.000 & 54.25 & 0.000 & 20.50 & 0.000 & 36.34 & 0.007 & 20.91 & 0.000 & 29.62 & 0.002 \\
\hline /cut5 & 22.41 & 0.000 & 63.76 & 0.000 & 24.02 & 0.000 & 20.01 & 0.000 & 23.57 & 0.000 & 57.31 & 0.000 & 22.02 & 0.000 & 46.81 & 0.005 & 22.44 & 0.000 & 31.09 & 0.001 \\
\hline /cut6 & 23.24 & 0.000 & 64.61 & 0.000 & 24.60 & 0.000 & 20.70 & 0.000 & 24.39 & 0.000 & 58.05 & 0.000 & 24.42 & 0.000 & 50.57 & 0.002 & 24.89 & 0.000 & 37.87 & 0.001 \\
\hline /cut7 & 25.38 & 0.000 & 66.78 & 0.000 & 26.97 & 0.000 & 23.79 & 0.000 & 26.53 & 0.000 & 61.31 & 0.000 & 26.14 & 0.000 & 53.29 & 0.001 & 26.55 & 0.000 & 41.29 & 0.000 \\
\hline /cut8 & 27.12 & 0.000 & 68.56 & 0.000 & 28.84 & 0.000 & 25.59 & 0.000 & 28.28 & 0.000 & 63.09 & 0.000 & 32.26 & 0.000 & & & 32.67 & 0.000 & 43.60 & 0.000 \\
\hline /cut9 & 29.39 & 0.000 & 70.88 & 0.000 & 31.19 & 0.000 & 28.13 & 0.000 & 30.54 & 0.000 & 65.93 & 0.000 & & & & & & & 46.85 & 0.000 \\
\hline /cut10 & 31.10 & 0.000 & 72.64 & 0.000 & 32.89 & 0.000 & 29.95 & 0.000 & 32.25 & 0.000 & 67.87 & 0.000 & & & & & & & & \\
\hline /cut11 & 36.90 & 0.000 & 78.58 & 0.000 & 38.99 & 0.000 & 36.01 & 0.000 & 38.05 & 0.000 & 74.74 & 0.000 & & & & & & & & \\
\hline LR & \multicolumn{2}{|c|}{0.0000} & \multicolumn{2}{|c|}{0.0000} & \multicolumn{2}{|c|}{0.0000} & \multicolumn{2}{|c|}{0.0000} & \multicolumn{2}{|c|}{0.0000} & \multicolumn{2}{|c|}{0.0000} & \multicolumn{2}{|c|}{0.0000} & \multicolumn{2}{|c|}{0.0000} & \multicolumn{2}{|c|}{0.0000} & \multicolumn{2}{|c|}{0.0000} \\
\hline Wald & \multicolumn{2}{|c|}{0.0000} & \multicolumn{2}{|c|}{0.0000} & \multicolumn{2}{|c|}{0.0000} & \multicolumn{2}{|c|}{0.0000} & \multicolumn{2}{|c|}{0.0000} & \multicolumn{2}{|c|}{0.0000} & & & 0.00 & & 0.0 & & 0.0 & \\
\hline no obs & 4 & & & & 42 & & & & 49 & & 3 & & & & 80 & & 3 & & $\mathrm{~s}$ & \\
\hline no group & 1 & & & & 1 & & & & 1 & & 1 & & & & 3 & & 1 & & & \\
\hline
\end{tabular}

Source: Own calculations 
Table 6: Determinants influencing S\&P's banks' credit ratings by taking into consideration the size of banks and their capitalization

\begin{tabular}{|c|c|c|c|c|c|c|c|c|c|c|c|c|c|c|c|c|c|c|}
\hline \multirow{2}{*}{ S\&P } & \multicolumn{10}{|c|}{ S\&P } & \multicolumn{2}{|l|}{ Big } & \multicolumn{2}{|c|}{ Small } & \multicolumn{2}{|c|}{ Big cap } & \multicolumn{2}{|c|}{ Small cap } \\
\hline & Coef. & $P>z$ & Coef. & $P>z$ & Coef. & $P>z$ & Coef. & $P>z$ & Coef. & $P>z$ & Coef. & $P>z$ & Coef. & $P>z$ & Coef. & $P>z$ & Coef. & $P>z$ \\
\hline opl & -.0011 & 0.341 & -.0012 & 0.304 & -.0022983 & 0.086 & -.0020167 & 0.164 & -.0015629 & 0.250 & -.0075228 & 0.006 & -.0004711 & 0.797 & -.0016682 & 0.430 & -.0010483 & 0.602 \\
\hline lev & .0109 & 0.394 & .0096 & 0.466 & .0028474 & 0.833 & -.002884 & 0.836 & .0314963 & 0.044 & .1437775 & 0.000 & .0546198 & 0.006 & .1194745 & 0.001 & .0016187 & 0.918 \\
\hline$\| p$ & .2892 & 0.262 & .3617 & 0.184 & .5581274 & 0.071 & .4110579 & 0.145 & .4770655 & 0.069 & -.2275096 & 0.802 & .3957475 & 0.235 & .1051124 & 0.895 & .4211573 & 0.208 \\
\hline tier1 & -.0029 & 0.895 & -.0406 & 0.087 & -.1097006 & 0.000 & -.1739125 & 0.000 & -.0627632 & 0.008 & .0753221 & 0.019 & -.2028102 & 0.000 & .0642223 & 0.042 & -.0908647 & 0.092 \\
\hline dep & -.2114 & 0.332 & -.3547 & 0.115 & -.6341966 & 0.214 & 1.205355 & 0.041 & -.2808203 & 0.207 & .4758758 & 0.346 & -2.114972 & 0.010 & .4388729 & 0.279 & -1.647618 & 0.037 \\
\hline sec & .0034 & 0.684 & .0033 & 0.686 & .0005209 & 0.952 & -.0059744 & 0.583 & .0125072 & 0.142 & .0027721 & 0.734 & .0327805 & 0.367 & .0021036 & 0.804 & -.0277336 & 0.555 \\
\hline roa & .4169 & 0.196 & .5934 & 0.088 & 1.016213 & 0.012 & .6387635 & 0.067 & .6552858 & 0.043 & 3.066742 & 0.002 & -.1032372 & 0.792 & 2.701823 & 0.001 & .038414 & 0.930 \\
\hline liq & -4.0189 & 0.004 & -5.1172 & 0.000 & -3.267952 & 0.052 & -1.608852 & 0.402 & -4.779798 & 0.001 & -.0152748 & 0.993 & -16.18952 & 0.000 & -.9078932 & 0.600 & -12.02762 & 0.005 \\
\hline $\lg$ & -.4161 & 0.070 & -.3814 & 0.103 & -.2360462 & 0.345 & -1.071326 & 0.006 & -.4436565 & 0.057 & -.2373638 & 0.448 & -.9358057 & 0.048 & -.2127222 & 0.490 & -.6672605 & 0.159 \\
\hline dg & .1482 & 0.797 & .1492 & 0.798 & -.3889058 & 0.568 & .6904464 & 0.352 & .0317135 & 0.956 & .2162608 & 0.735 & -.086887 & 0.959 & .1876093 & 0.771 & .1618562 & 0.929 \\
\hline sht & -.4325 & 0.370 & -.4048 & 0.423 & -.979002 & 0.086 & -.7929196 & 0.137 & -.7066758 & 0.149 & -5.09349 & 0.104 & -.0189888 & 0.977 & -6.844685 & 0.003 & -.2231756 & 0.738 \\
\hline gdpg & -.0227 & 0.310 & .0009 & 0.966 & .0688144 & 0.010 & -.0166369 & 0.550 & -.1142067 & 0.000 & .0635774 & 0.054 & -.0070447 & 0.867 & .0622923 & 0.064 & -.0250843 & 0.637 \\
\hline cr_sp & .4118 & 0.000 & .4313 & 0.000 & .4635708 & 0.000 & .4591953 & 0.000 & .4093846 & 0.000 & .3284448 & 0.000 & .5865789 & 0.000 & .3752728 & 0.000 & .4797129 & 0.000 \\
\hline ass & & & 1.8309 & 0.000 & & & & & & & & & & & & & & \\
\hline assgdp & & & & & .0438374 & 0.000 & & & & & & & & & & & & \\
\hline capgdp & & & & & & & .0036753 & 0.609 & & & & & & & & & & \\
\hline cap & & & & & & & & & 1.47771 & 0.000 & & & & & & & & \\
\hline /cut1 & .02 & 0.986 & 45.13 & 0.000 & 16.33892 & 0.000 & 11.30103 & 0.000 & 30.31387 & 0.000 & 12.19142 & 0.000 & -7.395893 & 0.003 & 12.16734 & 0.000 & -3.793716 & 0.113 \\
\hline /cut2 & .76 & 0.600 & 46.00 & 0.000 & 19.6391 & 0.000 & 14.85258 & 0.000 & 31.10137 & 0.000 & 15.93872 & 0.000 & -6.639205 & 0.006 & 14.77298 & 0.000 & -3.028689 & 0.190 \\
\hline /cut3 & 10.13 & 0.000 & 56.58 & 0.000 & 21.42435 & 0.000 & 16.90649 & 0.000 & 42.24099 & 0.000 & 17.1811 & 0.000 & 4.626542 & 0.042 & 15.28343 & 0.000 & 8.511317 & 0.000 \\
\hline /cut4 & 13.75 & 0.000 & 59.92 & 0.000 & 23.38698 & 0.000 & 19.11938 & 0.000 & 45.73506 & 0.000 & 18.16179 & 0.000 & 11.02529 & 0.000 & 16.25723 & 0.000 & 11.88081 & 0.000 \\
\hline /cut5 & 15.47 & 0.000 & 61.45 & 0.000 & 25.13854 & 0.000 & 20.98564 & 0.000 & 47.30091 & 0.000 & 22.95532 & 0.000 & 14.74076 & 0.000 & 19.02193 & 0.000 & 13.95483 & 0.000 \\
\hline /cut6 & 17.68 & 0.000 & 63.64 & 0.000 & 28.0696 & 0.000 & 23.93663 & 0.000 & 49.4931 & 0.000 & 25.42173 & 0.000 & 17.7281 & 0.000 & 22.37439 & 0.000 & 16.57182 & 0.000 \\
\hline /cut7 & 19.30 & 0.000 & 65.39 & 0.000 & 30.81243 & 0.000 & 26.77165 & 0.000 & 51.23907 & 0.000 & 27.65901 & 0.000 & 20.01661 & 0.000 & 25.5039 & 0.000 & 18.59462 & 0.000 \\
\hline /cut8 & 21.87 & 0.000 & 68.27 & 0.000 & 32.66941 & 0.000 & 28.82178 & 0.000 & 53.97501 & 0.000 & 30.11502 & 0.000 & 23.7758 & 0.000 & 28.09317 & 0.000 & 21.5798 & 0.000 \\
\hline /cut9 & 24.33 & 0.000 & 70.85 & 0.000 & 34.96563 & 0.000 & 31.44388 & 0.000 & 56.71268 & 0.000 & 31.77804 & 0.000 & 26.91632 & 0.000 & 32.63477 & 0.000 & 24.57727 & 0.000 \\
\hline /cut10 & 26.02 & 0.000 & 72.64 & 0.000 & 38.53721 & 0.000 & 35.31569 & 0.000 & 58.30647 & 0.000 & 34.93524 & 0.000 & 28.69834 & 0.000 & 34.75948 & 0.000 & 26.19962 & 0.000 \\
\hline /cut11 & 28.20 & 0.000 & 74.84 & 0.000 & 41.36256 & 0.000 & 37.63528 & 0.000 & 60.63161 & 0.000 & 37.20101 & 0.000 & 31.48634 & 0.000 & 38.25925 & 0.000 & 29.04224 & 0.000 \\
\hline /cut12 & 31.22 & 0.000 & 78.01 & 0.000 & 45.94832 & 0.000 & 42.53345 & 0.000 & 63.90079 & 0.000 & 42.26511 & 0.000 & 35.4728 & 0.000 & 40.60765 & 0.000 & 30.97585 & 0.000 \\
\hline /cut13 & 33.65 & 0.000 & 80.59 & 0.000 & 48.13131 & 0.000 & 44.61428 & 0.000 & 66.47061 & 0.000 & & & 40.95106 & 0.000 & 45.67255 & 0.000 & 34.95222 & 0.000 \\
\hline /cut14 & 37.71 & 0.000 & 84.84 & 0.000 & 52.62951 & 0.000 & 48.84156 & 0.000 & 70.65074 & 0.000 & & & 48.14793 & 0.000 & & & 40.88047 & 0.000 \\
\hline LR & \multicolumn{2}{|c|}{0.0000} & \multicolumn{2}{|c|}{0.0000} & \multicolumn{2}{|c|}{0.0000} & \multicolumn{2}{|c|}{0.0000} & \multicolumn{2}{|c|}{0.0000} & \multicolumn{2}{|c|}{0.0000} & \multicolumn{2}{|c|}{0.0000} & \multicolumn{2}{|c|}{0.0000} & \multicolumn{2}{|c|}{0.0000} \\
\hline Wald & \multicolumn{2}{|c|}{0.0000} & \multicolumn{2}{|c|}{0.0000} & \multicolumn{2}{|c|}{0.0000} & \multicolumn{2}{|c|}{0.0000} & \multicolumn{2}{|c|}{0.0000} & \multicolumn{2}{|c|}{0.0000} & 0.000 & & 0.000 & & 0.00 & \\
\hline no obs & 107 & & $10 \epsilon$ & & 977 & & 864 & & 106 & & 647 & & 425 & & 748 & & 324 & \\
\hline $\begin{array}{c}\text { no } \\
\text { group }\end{array}$ & 49 & & 49 & & 47 & & 46 & & 48 & & 27 & & 29 & & 35 & & 33 & \\
\hline
\end{tabular}

\section{Source: Own calculations}

contrast to the ratings assigned by Moody's. For Fitch, this variable is insignificant.

The analysis of the macroeconomic condition has been prepared by using the GDP growth and the countries' credit ratings. The strongest reaction to GDP growth has been observed in the case of the notes given by Fitch. The analysis suggests that for both bigger and smaller banks this determinant has been significant. A stronger reaction has been noticed in the case of all types of ratings, in the case of bigger banks. These institutions are one of the most significant investors in government securities. Their activity is also strictly connected with the stage of the 
business cycle. In the current methodologies an opinion has been presented according to which a relationship between the countries' and the banks' ratings has been observed. On the other hand, during the analysis of the factors that influence countries' notes we can find a similar estimation method to those presented for banks. As a result, the "golden rule" can still exist. The research confirms it. Countries' notes influence statistically significantly banks' credit ratings, especially in relation to the smaller institutions. Bigger international financial institutions are usually independent from countries' credit ratings because their business is connected with the economic condition of various countries.

The next part of the analysis relies on the verification of the impact of the size of the banking sector, the size of banks, the capitalization of the financial market and banks' capitalization. If banks are bigger, credit ratings are higher, but it depends on the customer of credit rating agencies. Fitch in their portfolio estimates notes of smaller banks, and as a result this relationship has not been observed. A different situation was seen for Moody's and S\&P's. Their main clients are large financial institutions, and as a result the impact is confirmed. The size of the banking sector has a positive impact on banks' notes for all analyzed credit rating agencies. The same situation has been noticed for market capitalization. Bank capitalization is also a significant determinant of banks' notes. The Fitch ratings are the notes most sensitive to these changes.

\section{Conclusions}

The aim of the paper was to analyze the factors influencing European banks' credit ratings by taking into account the size of the institutions. The following hypotheses have been drawn: banks' capital adequacy, profitability, liquidity and management quality have a significant influence on their credit ratings. Bigger banks receive higher credit ratings than the smaller ones in similar financial conditions.
The presented hypotheses have been confirmed. The analysis also helps to find differences between the impact of the group of factors on the banks' notes by considering the size of the estimated institutions. For Fitch, capital adequacy, asset quality and management indicators are significant for bigger banks. Earnings determinants are especially important for smaller institutions if we take into consideration the loan growth, and for the bigger ones if we analyze the rates of return. Liquidity indicators are important for both groups, but the strength of impact is higher for smaller institutions. The macroeconomic indicators have a similar impact on the Fitch notes.

Moody's credit ratings put into consideration the capital adequacy indicators both for smaller and bigger banks (tier 1 is significant for both groups, the leverage ratio for large banks). The same situation has been observed for the management quality, earnings and liquidity indicators. The notes given to bigger banks are sensitive to the assets quality factors. The impact of the GDP growth is stronger for larger institutions, and countries' credit ratings - for the smaller ones.

Notes that are presented by S\&P's for European banks are insensitive to assets quality and management quality indicators in both groups by taking into account the size of assets and the value of the capitalization market. The notes that are given to large banks are dependent on the earnings and capital adequacy factors, but those prepared for smaller institutions are correlated with the liquidity and capital adequacy indicators.

The presented results suggest that smaller banks are more sensitive to credit ratings than the bigger ones. As a result, in the next study the impact of the business cycle on banks' credit ratings, and the changes to these notes in the sample of bigger and smaller banks during the crisis will be analyzed. The analysis will be extended by the notes that are prepared not only by bigger but also by smaller credit rating agencies.

\section{REFERENCES}

Bellotti, T., Matousek, R., Stewart, C. (2011a). A Note Comparing Support Vector Machines and Ordered Choice Models' Predictions of International Banks' Rating. Decision Support Systems, 51(3), 682-687.

Bellotti, T., Matousek, R., Stewart, C. (2011b). Are Rating Agencies' Assignments Opaque? Evidence from International Banks. Expert Systems with Applications, 38(4), 4206-4214. 
Bissoondoyal-Bheenick, E., Treepongkaruna, S. (2011). An Analysis of the Determinants of bank ratings: comparison across ratings agencies. Australian Journal of Management, 36(3), 405 -424.

Brezigar-Masten, A.,Masten, I., Volk, M. (2015). Discretionary Credit Rating and Bank Stability in a Financial Crisis, Eastern European Economics, 53(5), 377-402.

Chodnicka - Jaworska, P. (2016). Banks credit ratings - is the size of the credit rating agency important?. Working paper.

Estrella, A., Park, S.,Peristiani, S. (2000). Capital Ratios as Predictors of Bank Failure. FRBNY Economic Policy Review, July, 33-52.

Ferri, G., Liu, L.G., Stiglitz, J.E. (1999). Are Credit Ratings Pro-cyclical? Evidence from East Asian Countries. Economic Notes, 28(3), 335-55.

Hassan, O.A.G, Barrell, R. (2013). Accounting for the Determinants of Banks' Credit Ratings. Brunel University of London Economics and Finance Working Paper Series, 13-02.

Hau, H., Langfield, S., Marques-Ibanez, D. (2012). Bank Ratings what Determines their Quality? EBC Working Paper Series, 1484, October.

Jacobson, T., Lindé, J., Roszbach, K. (2006). Internal Ratings Systems, Implied Credit Risk and the Consistency of Banks' Risk Classification Policies. Journal of Banking \& Finance, 30(7), 1899-1926

King, M.K., Ongena, S., Tarashev. N. (2016). Bank standalone creditratings. BIS Working Papers, 542, 1-62.

McDonald, A., Eastwood, G. (2000). Credit Risk Ratingat Australian Banks.APRA Working Papers, 7, December, 1-32.

Öğüt, H., Doğanay, M.M., Ceylan, N.B., Aktaş, R. (2012). Prediction of Bank Financial Strength Ratings: The Case of Turkey. Economic Modelling, 29, 632-640.

Ötker-Robe, I., Podpiera, J. (2010). The Fundamental Determinants of Credit Default Risk for European Large Complex Financial Institutions. IMF Working Paper, WP/10/153.

Packer, F., Taraschev, N. (2011). Rating Methodologies for Banks. BIS Quarterly Review, June.

Pagratis, S., Stringa, M. (2007). Modelling Bank Credit Ratings: A Structural Approach to Moody's Credit Risk Assessment. Athens University of Business and Economics Working Paper.

Poon, W.P.H., Firth, M., Fung, H. (1999). A Multivariate Analysis of The Determinants of Moody's Bank Financial Strength Ratings. Journal of International Financial Markets, Institutions and Money, 9(3), 267-283.

Poon, W., Lee, J., Gup, B.E. (2009). Do Solicitations Matter In Bank Credit Ratings? Results from a Study of 72 Countries. Journal of Money, Credit and Banking, 41, 285-314.

Shen, C., Huang, Y., Hasan, I. (2012). Asymmetric Benchmarking in Bank Credit Rating. Journal of International Financial Markets, Institutions \& Money, 22, 171- 193. 